\title{
ENHANCEMENT OF THE QUALITY OF HUMAN RESOURCES THROUGH TRAINING AND DEVELOPMENT PROGRAMS IN SCHOOLS
}

\author{
Charlita Trihapsari1, Fadhilah Mujahidah ${ }^{2}$, Neneng Humairoh ${ }^{3}$ \\ Islamic Educational Management Department, Universitas Islam Negeri Syarif Hidayatullah \\ Jakarta, Indonesia \\ Email: charlita.trihapsari20@mhs.uinjkt.ac.id ${ }^{1}$, fadhilah.mujahidah20@mhs.uinjkt.ac.id ${ }^{2}$, \\ nenenghumairoh89@gmail.com ${ }^{3}$
}

DOI: http://doi.org/10.33650/al-tanzim.v5i2. 2325

\begin{tabular}{l|l|l} 
Received: June 2021 & Accepted: July 2021 & Published: August 2021
\end{tabular}

\begin{abstract}
:
This study aims to analyze and understand the training and development program carried out by SMP YAMIS Jakarta in improving the quality of its human resources. This research uses a qualitative case study approach. The data collection technique is done through interviews, observation, and documentation. Data analysis is done through data presentation, data reduction, and concluding. The results showed that the training and development program carried out by SMP YAMIS Jakarta in improving the quality of its human resources was through the Subject Teacher Consultation (MGMP) activities which were carried out periodically by the existing schedule, involving teachers in seminars on learning methods that creative, innovative and fun, holding independent training in schools by inviting resource persons who are experts in the field, and programmed supervision carried out by school principals to employees regarding the achievement of planned educational goals.
\end{abstract}

Keywords: Training and Development, Quality, Human Resources

Abstrak:

Penelitian ini bertujuan untuk menganalisis dan memahami tentang program pelatihan dan pengembangan yang dilakukan oleh SMP YAMIS Jakarta dalam meningkatkan kualitas sumber daya manusianya. Penelitian ini menggunakan pendekatan kualitatif jenis studi kasus. Teknik pengumpulan datanya dilakukan melalui interview, observasi, dan dokumentasi. Analisis datanya dilakukan melalui penyajian data, reduksi data dan penarikan kesimpulan. Hasil penelitian menunjukkan bahwa program pelatihan dan pengembangan yang dilakukan oleh SMP YAMIS Jakarta dalam meningkatkan kualitas sumber daya manusianya adalah melalui kegiatan Musyawarah Guru Mata Pelajaran (MGMP) yang dilakukan secara periodik sesuai dengan schedule yang ada, mengikut sertakan guru dalam kegiatan seminar tentang metode pembelajaran yang kreatif, inovatif dan menyenangkan, mengadakan pelatihan mandiri di sekolah dengan mengundang nara sumber yang ahli dalam bidang tersebut, dan supervisi terprogram yang dilakukan oleh kepala sekolah kepada pegawai terkait ketercapaian tujuan pendidikan yang telah direncanakan

Kata Kunci: Pelatihan dan Pengembangan, Kualitas, Sumber Daya Manusia 


\section{INTRODUCTION}

The organization must have strength in dealing with its competitors. One that can support this is the assets owned by the organization, namely human resources, which play an essential role in the journey of the organization's wheels. HR has a significant role in every organizational activity (Mundiri, 2015; Yuliyati, 2020). lthough supported by facilities and infrastructure and promising sources of funds, without the support of reliable human resources, organizational activities will not be completed properly. This shows that human resources are the primary key that must be considered with all their needs (Silviani et., 2021). HR is the most crucial resource of an organization which implies that its development must be regarded as an investment (Ranabahu \& Almeida, 2019). Indeed the results will not be seen immediately, but in the long run, this investment will yield results that may be above the organization's expectations (Kambey, 2013; Tiwa et al., 2018).

We often hear about training and development in the world of work in companies, organizations, institutions, or even educational institutions (Kalangi et al., 2021). The organization's training and development aim to improve various skills and techniques for carrying out specific, detailed, and routine work (Khurotin \& Afrianty, 2018). Training and development are often carried out in educational institutions to improve personnel who are considered unable to carry out their work correctly (Sunasi et al., 2019). This encourages the management of educational institutions to facilitate training and career development of their personnel to obtain good, effective, and efficient performance results.

Education and training are tools to adjust tasks and jobs with each employee's abilities, skills or skills, and expertise and efforts to improve employee performance as an introduction activity to specific jobs for those concerned (Amir, 2019; Yohanes, 2019). Whether or not employee performance will affect the stability of an organization in achieving the goals set (Ningrum, 2013; Rohmah, 2018).

By the results of the initial observations of researchers in the field, it was found that there were several personnel at SMP Yamis who did not have the required competencies in certain positions, thus hampering the achievement of organizational goals. Likewise, some teachers have not been able to carry out their teacher duties optimally and adequately. This is because the educational background is not by the material being taught, which implies that the results are less than optimal.

Departing from this, the SMP Yamis strives to overcome these various problems by providing education and training to develop the potential and competence of personnel in the institution. This is due to the principal's strategic steps to strengthen the quality of human resources to achieve school quality through several pieces of training and developments.

Given the importance of this training and development, Handayani (2019) and Audah (2020) said in their research results that education and training, motivation, and work environment have a positive and significant influence on teacher performance in schools. Hariwirawan (2020) and Djajadi 
(2020) said a significant contribution between education and training on the quality of teacher learning management in the classroom. Santoso et al., (2020) added that education and training could improve teacher achievement in schools.

Likewise, with the importance of human resources for the sustainability of schools to increase their competitive advantage. Yuliyati (2020), in her research results, said that improving the quality of human resources in schools must be carried out in a planned and systematic way through the integration of total quality management in its implementation. Cahyo (2017) said that to improve school competitiveness, serious management of its human resources is needed, starting from planning, recruitment and selection, training and development, and an ideal compensation system. Zakiatul \& Hasan (2019) added that what needs to be developed in applying human resource management in the digital era is optimizing the use of information systems based on digital technology.

Some of these studies prove that training and human resource development have a significant and vital role in improving education and learning in schools. Changes will continue to occur if this training and development program is carried out in a planned, serious, and systematic manner. These activities are essentially aimed at forming qualified and qualified human beings. SMP YAMIS Jakarta continues to innovate in implementing programs to improve the quality of its education through training and human resource development activities. Therefore, researchers are interested in studying and understanding the training and development program SMP YAMIS Jakarta carried out in improving the quality of its human resources.

\section{RESEARCH METHODS}

This research uses a qualitative approach with the type of case study. The researcher, in this case, is a crucial instrument, meaning that the researcher positions himself as a planner, implementer in the field to collect, analyze and interpret data according to the theme being studied.

The data collection technique is carried out through observation, interviews, and documentation to obtain information about the training and development program carried out by SMP YAMIS Jakarta to improve the quality of its human resources. Data analysis was carried out circularly, starting from data collection, data reduction, and concluding research findings.

\section{RESULTS AND DISCUSSION}

SMP YAMIS Jakarta stands on land owned by the Miftahus Sa'adah Foundation, located on Jl. Bambularangan RT 001 RW 09 Pegadungan subdistrict, Kalideres sub-district, West Jakarta. The Ministry of Education and Culture of Jakarta's Special Capital Region approved establish/operate schools for SMP YAMIS Jakarta. During its establishment, SMP YAMIS Jakarta had hopes and objectives. Students have noble character, are capable, uphold religious values and norms, and have a good and quality future. 
In addition to the educational objectives mentioned above, SMP YAMIS Jakarta aims to improve the quality of its personnel so that the targets to be achieved can be realized optimally. The strategies undertaken to develop human resources in the institution are; first, increasing the qualifications of educators to take part in the master's program, at least $20 \%$ of the existing teachers; second, include periodic teacher certification; third, improving the academic, professional, social and personal competencies of teachers and employees through in-house training; fourth, improve ICT competence for all teachers and employees.

The training and human resource development program at SMP YAMIS Jakarta is carried out to improve the quality of human resources at the institution. The training and development program at the institution is no longer seen as an obligation but should have become a necessity to prepare qualified and competent human resources. To achieve this goal, SMP YAMIS Jakarta held several training and development programs for its teachers in a planned and systematic manner, including; First, having a Subject Teacher Deliberation activity, where this forum is a forum that facilitates teachers in each of the same subjects to develop work professionalism together. Rusmiyati said this activity helped her understand many things, especially about strategies to make English learning more effective through exchanging experiences with colleagues.

Likewise, with the narrative of the Deputy Principal of the Curriculum Section, who said that the Subject Teacher Deliberation activities were held every month, some even had it every two weeks. This is intended to assist teachers in overcoming the various difficulties they experience with their peers.

This activity refers to improving the competence and professionalism of teachers in specific fields of study. The usual activities include; discussion about problems that occur in the learning process. For example, how to increase students' motivation and interest in learning in the subjects taught, compiling and developing a syllabus, semester programs, and learning program plans, deepening teaching materials, training on mastery of materials that support the learning process, classroom action research, and so on.

Second, workshops or training are part of the human investment to improve work skills and abilities to improve employee performance. Based on the results of interviews with Baihaki as a teacher at SMP YAMIS, he said that the workshop activities given to teachers were based on the need to update the techniques/methods used in learning.

Suryani also conveyed the same thing as the SMP YAMIS, who said that workshops for teachers were implemented at least two times in 1 semester. This is adjusted to the needs that have been previously planned through the school work program, where the need for human resource development is necessary for each academic year to develop the potential and competence of teachers and employees.

This shows that the development of human resources at SMP Yamis Jakarta is carried out in a planned and systematic manner, based on the school work plan prepared together to achieve the predetermined goals. The 
implementation of the workshop, as conveyed by the informant, shows the school's commitment to carry out the work program that has been determined to develop the potential and competence of teachers and employees through workshop activities.

Third, online seminar activities (Webinar). The webinar is a term used to refer to virtual seminars or online seminars, including part of a distributed education program. During the Covid 19 pandemic, most training, and development activities were conducted online, one of which was webinars. Based on information from Rina Mediawati as a teacher at SMP YAMIS Jakarta Junior High School, the webinar conducted for teachers at SMP YAMIS Jakarta Junior High School came from the DKI Jakarta Department of Education and Culture. The webinars provided so far have been very useful in enriching teachers' sources, methods, and techniques in teaching during online learning.

Based on information from Suryani as the principal of the SMP YAMIS, who said that the implementation of webinars during the pandemic was more than other training and development programs. This is due to the convenience of teachers in managing their time to participate in various activities because it does not require a lot of space and money.

The existence of the webinar shows that SMP YAMIS can manage social and cultural changes in the community during the pandemic, where the school continues to carry out human resource development activities even in difficult times, namely during the pandemic, with a record of maintaining the health protocol.

Fourth, Curriculum 2013 (K-13). The curriculum used at SMP YAMIS Jakarta changed from the Education Unit Level Curriculum to the 2013 Curriculum. To deepen information about the 2013 curriculum, SMP YAMIS delegated its teachers to participate in the socialization and training of the 2013 Curriculum held by the West Jakarta Education Office.

The 2013 curriculum is the applicable curriculum in the Indonesian Education System as a form of improvement from the previous curriculum. This curriculum is a new curriculum established and implemented by the government to replace the 2006 Curriculum (often referred to as the Education Unit Level Curriculum), which has been in effect for approximately six years. The 2013 curriculum entered its probationary period 2013 by turning several schools into pilot schools.

Based on information obtained from Salahuddin, the K-13 training was carried out with an in on in the system, which means that the training was conducted outside the school for some time. For some time, the trainer came to the school to see the application of the activity that had been done previously.

The results of the training and development program carried out by the SMP YAMIS Jakarta can be seen from the success of teachers in increasing the score of the Android-Based School exam results held in 2020 and 2021. In 2020, the average score of the 9th-grade Android-Based School Exam, which consists of 82 students, was 79.38, with the highest average score of 82.77 and the lowest 71.85. Meanwhile, in 2021, out of 69 9th grade students who carried out USBA, 
an average score of 81.86 was obtained. The highest average value also increased at 88.2, and the lowest average value became 78.2.

The teacher's success in improving the student's test scores indicates that the training and human resource development program at SMP YAMIS Jakarta is quite successful or effective. Training and development of human resources have a vital and urgent role in the reality of both in the world of education. Training is a series of activities that are structured in a directed manner to improve skills, experience, expertise, increase knowledge and change an individual's attitude (Syamsuddin, 2017; Rusdi, 2018).

In-Law Number 13 of 2003 concerning employment, the definition of job training is all activities to provide, obtain, improve and develop work competence, productivity, discipline, attitude and work ethic at specific skill and expertise levels by the level and qualifications of the position. Development is a consequence of education and training, which is defined as the preparation of individuals to assume responsibility for improving and enhancing knowledge, abilities, attitudes, and personality traits. The implementation of this development is more formal, and its concentration leads to strategies to prepare employees' abilities for future positions. Development goals must be able to change the attitudes, behavior, experiences, and performance of employees.

Human resource development aims to improve teacher teaching abilities, increase motivation and job satisfaction and eliminate boredom in carrying out tasks (Afriyanti, 2018; Islam et al., 2018). The principal has a very strategic role in developing human resources; however, the principal involves various supporting components (Wahyono, 2019). Problems related to the need for human resource development faced by schools relate to community demands for the quality of education that must be further improved (Dakir, 2018). The teaching quality of teachers who still do not show a professional attitude and learning achievements achieved by students still do not show good results. Efforts made by school principals in developing the quality of human resources in elementary schools include: providing training, performance management, career planning, and providing welfare (Umiarso, 2016; Fauzi, 2019; Septantiningtyas \& Zainab, 2020).

The purpose of training and development is to improve the affective (attitude), cognitive (knowledge), and psychomotor (behavioral) abilities of employees, as well as to prepare employees to face the changes that occur so that they can overcome obstacles that arise in their work (Bariqi, 2018). Changes will continue to occur. Therefore the importance of training and development programs must continue to be carried out and developed. All of that is nothing but to form quality and quality human beings (Elbadiansyah, 2011; Amir, 2019; Fadhli, 2020) .

SMP YAMIS Jakarta continues to innovate in implementing programs related to the quality of institutional education. Of course, the role of all educated citizens is the main factor in the running of the program. Both principals, teachers, and other employees will never be satisfied until here; they 
continue to improve the quality of education in various ways that have been planned according to the needs and applicable laws.

\section{CONCLUSION}

SMP YAMIS Jakarta is an educational institution that is fully aware of the shortcomings and lack of educational goals. However, it does not stop there; various efforts are continuously made to improve the quality of education. Among them are training programs and human resource development, which are carried out through training carried out by groups of "subject teacher deliberation," which are carried out regularly, attending workshops and seminars or webinars related to creative, innovative, and fun learning methods. The school also conducts independent training in schools by inviting resource persons who are experts in the field. The school principal also carries out programmed supervision of employees regarding the achievement of the planned educational goals.

Training programs and human resource development at SMP YAMIS Jakarta need to be further developed to accommodate the times and technological advances to create more effective and efficient educational planning programs through steps and strategies that are in line with current needs. Principals, teachers, and school staff can be involved in various training and human resource development, whether conducted by local governments, central government, or independent activity held by the agency. Principal policies related to human capital must be supported, mutually helpful, complementary, and beneficial for both parties so that the goals and benefits of HR training and development at SMP YAMIS Jakarta can at least be felt by all.

\section{REFERENCES}

Afriyanti, N. K. dan T. W. (2018). Analisis Pelatihan dan Pengembangan Sumber Daya Manusia di PT Beon Intermedia Cabang Malang. Jurnal Administrasi Bisnis, 64(1), 195-204.

Amir. (2019). Membangun Budaya Mutu pada Lembaga Pendidikan Islam Menuju Madrasah Unggul. Al-Tanzim: Jurnal Manajemen Pendidikan Islam, 3(2), 1-12. https:// doi.org/10.33650/al-tanzim.v3i2.676

Audah, Z. (2020). Pengaruh Pendidikan dan Pelatihan Terhadap Kinerja Guru pada SMA Muhammadiyah Martapura. Jurnal Aplikasi Pelayaran dan Kepelabuhanan, 10(2), 159-174. https:/ / doi.org/10.30649/japk.v10i2.81

Bariqi, M. D. (2018). Pelatihan dan Pengembangan Sumber Daya Manusia. Jurnal Studi Manajemen dan Bisnis, 5(2), 64-69. https:/ / doi.org/10.21107/

Cahyo, A. N. (2017). Manajemen Sumber Daya Manusia (SDM) Pendidikan dalam Meningkatkan Daya Saing SDIT Ar-Rahmah Pacitan. Muslim Heritage, 1(2), 263-286.

Dakir. (2018). Pengaruh Gaya Kepemimpinan Situasional Kepala Sekolah dalam Supervisi Akademik terhadap Kompetensi Profesional dan Kinerja Guru. Yogyakarta: K-Media. 
Djajadi, M. (2020). Efektivitas Pendidikan dan Pelatihan Guru: Suatu Upaya Meningkatkan Kualitas Pengajaran Fisika. Jurnal Sipatokkong, 1(1), 30-44. Retrieved from https://ojs.bpsdmsulsel.id/index.php/sipatokkong

Elbadiansyah. (2011). Mutu Pendidikan pada Perguruan Tinggi Keagamaan: Dari Manajemen Kelembagaan hingga Konstruksi Kurikulum Interrelasi. Muaddib: Studi Kependidikan dan Keislaman, 7(1), 47-66. https://doi.org/10.24269/muaddib.v7n1.2017.47-66

Fadhli, M. (2020). Sistem Penjaminan Mutu Internal dan Eksternal pada Lembaga Pendidikan Tinggi. Al-Tanzim: Jurnal Manajemen Pendidikan Islam, 4(2), 171-183.

Fauzi, A. (2019). Epistemologi Pendidikan Islam Rahmatan Lil 'Alamin di Era Revolusi Industri 4.0; Sebuah Kajian Paradigmatik. Edureligia: Jurnal Pendidikan Agama Islam, 3(2), 92-100. Retrieved from http://jurnaljpi.com/index.php/JPI/article/view/28

Handayani, D. (2019). Pengaruh Pendidikan dan Pelatihan, Motivasi, serta Lingkungan Kerja terhadap Kinerja Guru SMK Negeri Banyuasin. Jurnal Ilmu Manajemen, 6(2), 140-150. https:/ / doi.org/10.32502/jimn.v6i2.1583

Hariwirawan, I. K. (2020). Kontribusi Pendidikan dan Pelatihan terhadap Kualitas Pengelolaan Pembelajaran. Indonesian Journal of Educational Development, 1(1), 45-51. https://doi.org/10.5281/zenodo.3760434

Islam, S., Muali, C., \& Ghufron, Moh Idil, I. M. (2018). To Boost Students ' Motivation and Achievement through Blended Learning to Boost Students Motivation and Achievement through Blended Learning. Journal of Physics: Conf. Series, 1114, 1-11.

Kalangi, S., Weol, W., Tulung, J., \& Rogahang, H. (2021). Principal Leadership Performance: Indonesian Case. The International Journal of Social Sciences World, 3(2), 74-89.

Kambey, F. L. (2013). Pengaruh Pembinaan, Pelatihan dan Pengembangan, Pemberdayaan dan Partisipasi terhadap Kinerja Karyawan. Diponegoro Journal of Management, 10(2), 142-151. https:/ / doi.org/10.14710

Khurotin, N., \& Afrianty, T. W. (2018). Analisis Pelatihan dan Pengembangan Sumber Daya Manusia di PT Beon Intermedia Cabang Malang. Jurnal Administrasi Bisnis (JAB), 64(1), 195-203.

Mundiri, A. (2015). Komitmen Organisasional Sumber Daya Manusia dalam Meningkatkan Mutu Pendidikan Pesantren. Pedagogik, 3(1), 88-105.

Ningrum, W. (2013). Pengaruh Pendidikan dan Pelatihan terhadap Kinerja Karyawan (Studi pada Karyawan Joint Operating Body Pertamina-Perto China East Java). Jurnal Administrasi Bisnis, 6(2), 1-8.

Ranabahu, N., \& Almeida, S. (2019). Creating Learning Communities through Flipped Classes: A Challenge, an Answer, or An Opportunity for Teaching Strategic Human Resource Management. International Journal for the Scholarship of Teaching and Learning, 13(3), 1-9. https://doi.org/10.20429/ijsotl.2019.130303

Rohmah, N. F. (2018). Pelatihan dan Pengembangan Sumber Daya Manusia. Intizam: Jurnal Manajemen Pendidikan Islam, 2(1), 1-11. 
Rusdi, R. (2018). Continues Improvement sebagai Upaya dalam Meningkatkan Mutu Pendidikan Pedesaan. Al-Tanzim: Jurnal Manajemen Pendidikan Islam, 2(2), 150-160. https:/ / doi.org/10.33650/al-tanzim.v2i2.396

Santoso, B. W. J., Nugroho, Y., \& Parapat, D. O. A. (2020). Pendidikan dan Pelatihan Penulisan Best practice untuk Meraih Predikat Guru Berprestasi bagi Guru SMA Negeri 1 Semarang dengan Metode Special Projects Assignments. Jurnal Panjar: Pengabdian Bidang Pembelajaran, 2(2), 52-60.

Septantiningtyas, N., \& Zainab, I. (2020). Strategi Perguruan Tinggi dalam Menjaga Sustainability Lembaga melalui Program Kemitraan. Managere: Indonesian Journal of Educational Management, 2(3), 354-365. https://doi.org/10.52627/ijeam.v2i3.66

Silviani, S., Maarif, M. A., \& Wibowo, A. (2021). Knowledge Sharing Management: Strategy for Improving the Quality of Human Resources. Al-Tanzim: Jurnal Manajemen Pendidikan Islam, 5(1), 129-139. https://doi.org/10.33650/al-tanzim.v5i1.1831

Sunasi, D., Kusjono, G., \& Nuryana, I. (2019). Pelatihan Manajemen Penguasaan Kelas dan Pembuatan Bahan Ajar bagi Tenaga Pengajar Sukarela Taman Belajar Kreatif Mekarsari. Jurnal Pengabdian Dharma Laksana, 2(1), 41-44. https://doi.org/10.32493/j.pdl.v2i1.3625

Syamsuddin. (2017). Penerapan Fungsi-fungsi Manajemen dalam Meningkatkan Mutu Pendidikan. Jurnal Idaarah, 1(1), 60-73.

Tiwa, T., Kambey, E., Naharia, O., \& Senduk, J. (2018). Effect of Supervision of Headmaster Learning and Achievement Motivation on Working Climate at Public Junior High School. International Journal of Advanced Educational Research, 3(3), 4-10.

Umiarso. (2016). Manajemen Mutu Pendidikan. Jakarta: Kencana.

Wahyono, I. (2019). Mengembangkan Iklim Organisasi di Sekolah dengan Menggunakan Model Tagiuri. Al-Tanzim: Jurnal Manajemen Pendidikan Islam, 3(2), 61-72. https://doi.org/10.33650/al-tanzim.v3i2.638

Yohanes, A. (2019). Pelatihan dan Pengembangan SDM: Teori dan Aplikasi. Jakarta: UKI Atma Jaya.

Yuliyati, E. (2020). Pengembangan Sumber Daya Manusia Berbasis Total Quality Management di SMK Muhammadiyah Prambanan. Al-Tanzim: Jurnal Manajemen Pendidikan Islam, 4(1), 24-35. https:/ / doi.org/10.33650/al-tanzim.v4i1.967

Zakiatul, S., \& Hasan, A. (2019). Implementasi Manajemen Sumber Daya Manusia di Era Digital: Studi Kasus di MTs Nurul Jadid. Al-Idarah: Jurnal Kependidikan Islam, 9(1), 49-57. 